\title{
BENEFICIARIES OF INTERNATIONAL PROTECTION TRAVELLING TO THEIR COUNTRY OF ORIGIN: CHALLENGES, POLICIES AND PRACTICES IN IRELAND
}

SAMANTHA ARNOLD

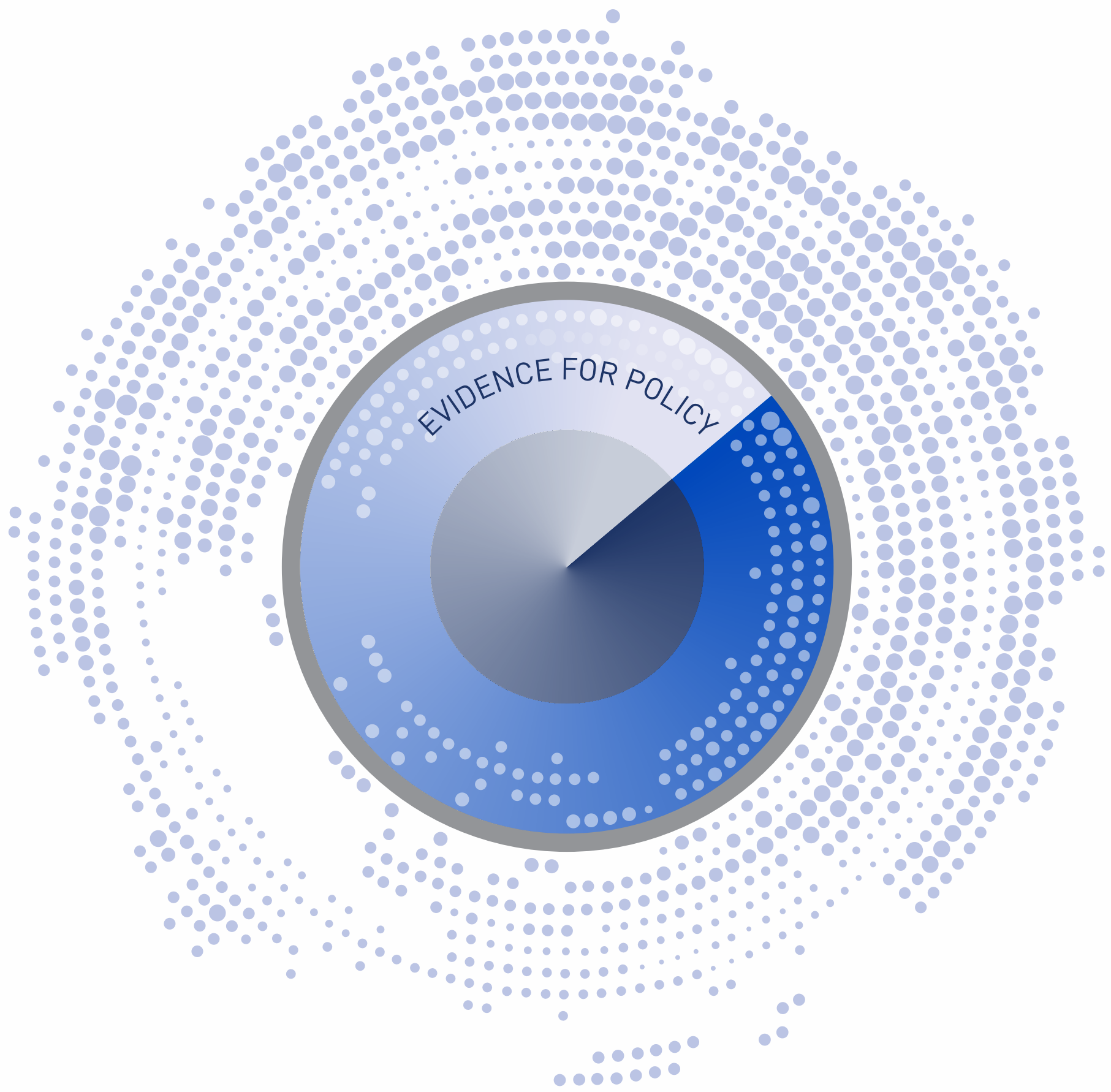





\section{BENEFICIARIES OF INTERNATIONAL PROTECTION TRAVELLING TO THEIR COUNTRY OF ORIGIN: CHALLENGES, POLICIES AND PRACTICES IN IRELAND}

Samantha Arnold

February 2019

ESRI SURVEY AND STATISTICAL REPORT SERIES

NUMBER 73

Study completed by the Irish National Contact Point of the European Migration Network (EMN), which is financially supported by the European Union and the Irish Department of Justice and Equality. The EMN was established via Council Decision 2008/381/EC.

Available to download from www.esri.ie

(C) The Economic and Social Research Institute

Whitaker Square, Sir John Rogerson's Quay, Dublin 2

ISBN 978-0-7070-0484-6

DOI https://doi.org/10.26504/sustat73.pdf

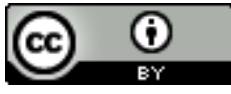

This Open Access work is licensed under a Creative Commons Attribution 4.0 International License (https://creativecommons.org/licenses/by/4.0/), which permits unrestricted use, distribution, and reproduction in any medium, provided the original work is properly credited. 


\section{THE EUROPEAN MIGRATION NETWORK}

The aim of the European Migration Network (EMN) is to provide up-to-date, objective, reliable and comparable information on migration and asylum at Member State and EU levels with a view to supporting policymaking and informing the general public.

The Irish National Contact Point of the European Migration Network, EMN Ireland, sits within the Economic and Social Research Institute (ESRI).

\section{ABOUT THE ESRI}

The mission of the Economic and Social Research Institute is to advance evidencebased policymaking that supports economic sustainability and social progress in Ireland. ESRI researchers apply the highest standards of academic excellence to challenges facing policymakers, focusing on 12 areas of critical importance to 21st Century Ireland.

The Institute was founded in 1960 by a group of senior civil servants led by Dr T.K. Whitaker, who identified the need for independent and in-depth research analysis to provide a robust evidence base for policymaking in Ireland.

Since then, the Institute has remained committed to independent research and its work is free of any expressed ideology or political position. The Institute publishes all research reaching the appropriate academic standard, irrespective of its findings or who funds the research.

The quality of its research output is guaranteed by a rigorous peer review process. ESRI researchers are experts in their fields and are committed to producing work that meets the highest academic standards and practices.

The work of the Institute is disseminated widely in books, journal articles and reports. ESRI publications are available to download, free of charge, from its website. Additionally, ESRI staff communicate research findings at regular conferences and seminars.

The ESRI is a company limited by guarantee, answerable to its members and governed by a Council, comprising 14 members who represent a cross-section of ESRI members from academia, civil services, state agencies, businesses and civil society. The Institute receives an annual grant-in-aid from the Department of Public Expenditure and Reform to support the scientific and public interest elements of the Institute's activities; the grant accounted for an average of 30 per cent of the Institute's income over the lifetime of the last Research Strategy. The remaining funding comes from research programmes supported by government departments and agencies, public bodies and competitive research programmes.

Further information is available at www.esri.ie. 


\section{THE AUTHORS}

Samantha Arnold was a Post-Doctoral Research Fellow at the Irish National Contact Point of the European Migration Network (EMN), within the ESRI.

\section{ACKNOWLEDGEMENTS}

In compiling this study, valuable assistance was received from representatives of the Irish Naturalisation and Immigration Service (INIS) within the Department of Justice and Equality and UNHCR Ireland, the UN Refugee Agency. Useful comments and suggestions were also received from Patricia Brazil BL., the study reviewers, and colleagues at the ESRI, Sarah Groarke, Christina Durst and Emma Quinn. Thanks also to Elaine Byrne and Sarah Burns for helping to bring the report to publication. The author is grateful to everyone who shared their expertise for the purpose of writing this study.

\section{ABOUT THIS REPORT}

This European Migration Network study looks at challenges, policies and practices regarding beneficiaries of international protection travelling to their country of origin. The report consists of information gathered by way of a common template, primarily for a forthcoming overview, EU-level synthesis report: Beneficiaries of international protection travelling to their country of origin: Challenges, Policies and Practices in the EU Member States, Norway and Switzerland, which will be published on www.emn.ie and www.ec.europa.eu/emn.

This report has been accepted for publication by the Institute, which does not itself take institutional policy positions. The report has been peer reviewed prior to publication. The authors are solely responsible for the content and the views expressed do not represent the position of the Economic and Social Research Institute, the Irish Naturalisation and Immigration Service, the Department of Justice and Equality, or the European Commission, Directorate-General Migration and Home Affairs. 



\section{TABLE OF CONTENTS}

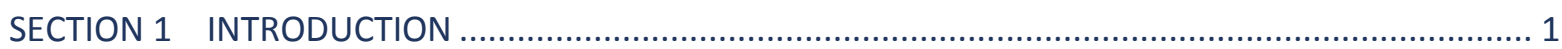

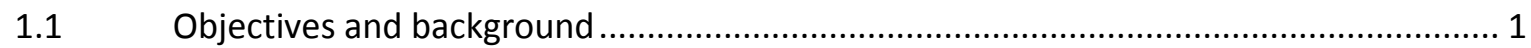

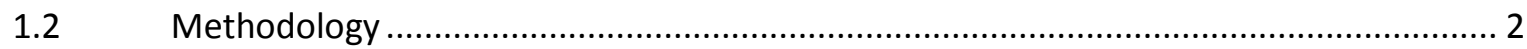

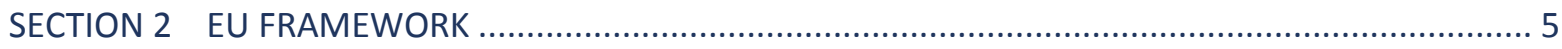

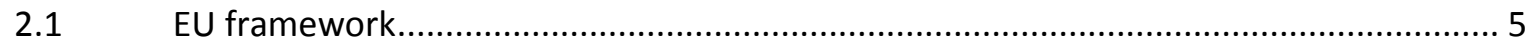

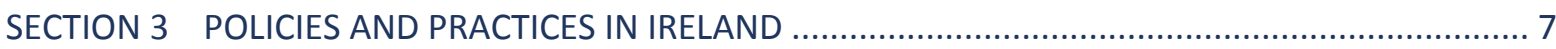

3.1 Cessation of refugee or subsidiary protection declarations in Ireland ............................ 7

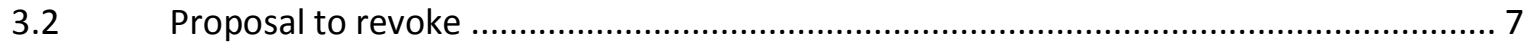

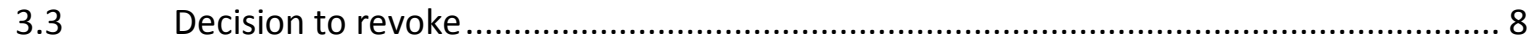

3.4 Grounds for revocation/cessation including return to/contact with country of origin ... 9

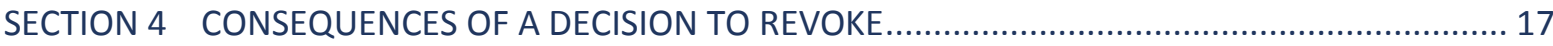

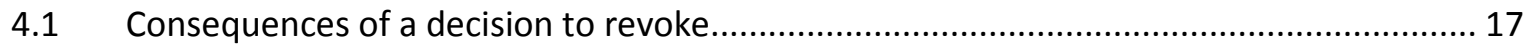

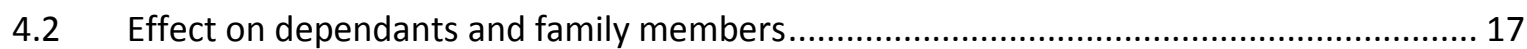

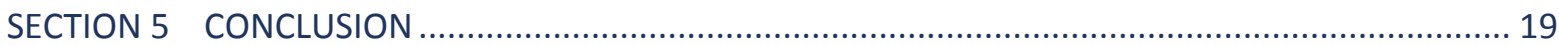





\section{SECTION 1}

\section{Introduction}

\subsection{OBJECTIVES AND BACKGROUND}

This report collates information on policies and procedures governing cessation and revocation of refugee and subsidiary protection in instances where beneficiaries travel to the country of origin or contact national authorities of the country of origin in Ireland. This report is based on information gathered according to commonly agreed EMN study specifications in preparing the Irish contribution to an EU-wide EMN study on Beneficiaries of international protection travelling to their country of origin: Challenges, Policies and Practices in the EU Member States, Norway and Switzerland. As with all EMN studies, a similar report was produced by the other EMN National Contact Points, and an EU-wide synthesis report will be compiled. ${ }^{1}$

The 1951 Convention relating to the Status of Refugees (Refugee Convention) provides certain circumstances whereby the Refugee Convention shall cease to apply unless the refugee can invoke compelling reasons for the protection of the host state not to cease. Pursuant to paragraphs (1) and (4) of Article 1C, the Refugee Convention may cease to apply where the refugee has voluntarily reavailed himself of the protection of the country of origin, or where he has reestablished himself there, respectively. Travelling to or contacting national authorities in the country of origin may result in cessation in accordance with Article 1C paragraphs (1) and (4). EU law is consistent with Article $1 \mathrm{C}$ of the Refugee Convention and provides grounds based on which international (both refugee and subsidiary) protection may come to an end (see Section 2.1).

Irish law also mirrors international and EU law and provides for cessation consistent with the Refugee Convention (see Section 3). Sections 9 and 11 of the International Protection Act 2015 govern cessation of refugee and subsidiary protection in Ireland. Cessation of Refugee Status under section 9 and subsidiary protection under section 11 form grounds for revocation under section 52 of the 2015 Act. 
National-level information on the reasons for cessation/revocation is not collected. ${ }^{2}$ The Irish Naturalisation and Immigration Service (INIS) noted that Ireland does not have a system of exit controls at the border. Therefore information on persons travelling to their country of origin is not captured in any data sources. $^{3}$

The Irish Refugee Council (IRC), ${ }^{4}$ INIS ${ }^{5}$ and the United Nations Refugee Agency Ireland (UNHCR Ireland) ${ }^{6}$ noted that while cessation is permitted under Irish law, it is not often applied in practice. UNHCR Ireland observed a reduction in the number of proposals to revoke in recent years.

No decisions had been issued to revoke a refugee/subsidiary protection declaration by the Minister under section 52 of the 2015 Act at the time of research (as at 21 February 2019). ${ }^{7}$ Revocation data on decisions between 2005 and 2014 and revocation appeals under the Refugee Act 1996 were made available by way of a parliamentary question in $2014 .^{8}$ More recent data are unavailable.

Section 2 of this report looks at the EU legislative framework governing cessation and revocation of international protection. Section 3 outlines the Irish policies and procedures governing cessation and revocation of international protection. Recent judgments are also discussed. Section 4 looks at the consequences of revocation of status.

\subsection{METHODOLOGY}

Desk research was undertaken at the outset, including a review of existing academic and policy-based literature. There is no available academic or civil society organisation literature on cessation and/or implications of beneficiaries travelling to countries of origin in Ireland within the temporal scope of the study. The IRC, Immigrant Council of Ireland (ICI), the Migrant and Refugee Rights Centre (Nasc), the Irish Human Rights and Equality Commission (IHREC), UNHCR

Interview with INIS, October 2018.

Ibid.

Irish Refugee Council (n.d.). Cessation and Review of Protection Status. Brussels: AIDA/ECRE. www.asylumineurope.org/reports/country/republic-ireland/content-protection/status-and-residence/cessation-andreview.

Interview with INIS, October 2018.

Interview with UNHCR Ireland, September 2018.

Correspondence with INIS, February 2019. See also: Irish Refugee Council (n.d.). Cessation and Review of Protection Status. Brussels: AIDA/ECRE. www.asylumineurope.org/reports/country/republic-ireland/content-protection/statusand-residence/cessation-and-review. IRC noted that no information was available on the number of cessation decisions made in 2017.

8 Parliamentary Question, 26 February 2014 [9747/14]. 
Ireland ${ }^{9}$ and the Law Society all published comments on various iterations of the International Protection Bill 2015. The IRC and Nasc were the only two NGOs to comment on cessation. The Law Society commented on revocation.

Interviews were undertaken with officials from UNHCR Ireland and the Irish Naturalisation and Immigration Service (INIS). EMN Ireland contacted three migrant NGOs who informed us that they did not have any experience with cessation in their work. Those interviewed for the present study noted that cessation in general is not a priority issue in Ireland. ${ }^{10}$

The cases reviewed in this study were determined in accordance with the Refugee Act 1996 and S.I. No. 518/2006 - European Communities (Eligibility for Protection) Regulations 2006. The International Protection Act 2015 repealed the 1996 Act and revoked the 2006 Regulations. No decision to revoke a refugee or subsidiary protection declaration had been issued under Section 52 of the 2015 Act at the time of research (as at 21 February 2019).

UNHCR Ireland (2015). UNHCR Comments on the General Scheme of the International Protection Bill. Dublin: UNHCR Ireland.

10 Interviews with: UNHCR Ireland, September 2018 and INIS, October 2018. 



\section{SECTION 2}

\section{EU framework}

\subsection{EU FRAMEWORK}

The recast Qualification Directive ${ }^{11}$ defines the conditions under which a thirdcountry national or stateless person ceases to be a refugee (Article 11) or a beneficiary of subsidiary protection (Article 16). In accordance with Article 11 a third-country national or a stateless person shall cease to be a refugee if he or she:

(a) has voluntarily re-availed himself or herself of the protection of the country of nationality; or

(b) having lost his or her nationality, has voluntarily re-acquired it; or

(c) has acquired a new nationality, and enjoys the protection of the country of his or her new nationality; or

(d) has voluntarily re-established himself or herself in the country which he or she left or outside which he or she remained owing to fear of persecution; or

(e) can no longer, because the circumstances in connection with which he or she has been recognised as a refugee have ceased to exist, continue to refuse to avail himself or herself of the protection of the country of nationality; or

(f) being a stateless person, he or she is able, because the circumstances in connection with which he or she has been recognised as a refugee have ceased to exist, to return to the country of former habitual residence.

In accordance with Article 16(1), a third-country national or a stateless person shall cease to be eligible for subsidiary protection when the circumstances which led to the granting of subsidiary protection status have ceased to exist or have changed to such a degree that protection is no longer required.

However, paragraphs 11(2) and 16(2) also note that Member States must consider whether the change of circumstances is of such a significant and nontemporary nature that the refugee's/beneficiary of subsidiary protection's fear of persecution/serious harm can no longer be regarded as well-founded.

11 Directive 2011/95/EU. 
Paragraphs $11(3)$ and $16(3)$ also limit the Member State's ability to cease protection where the refugee/beneficiary of subsidiary protection is able to invoke compelling reasons arising out of previous persecution/serious harm for refusing to avail themselves of the protection of their country of origin/previous habitual residence.

Cessation under Articles 11 and 16 form grounds for revocation under Articles 14 and 19 of the Qualification Directive recast. ${ }^{12}$ In line with UNHCR's guidelines, ${ }^{13}$ which recommend that cessation procedures should include the usual procedural safeguards, Articles 44, 45 and 46 of the recast Asylum Procedures Directive provide for such safeguards (e.g. to be informed; allowed make representations to challenge any proposal to revoke; decision to be made by a competent authority; and the right to an effective remedy on appeal) where international protection statuses may be ended, revoked or not renewed. ${ }^{14}$ 


\section{SECTION 3}

\section{Policies and practices in Ireland}

\subsection{CESSATION OF REFUGEE OR SUBSIDIARY PROTECTION DECLARATIONS IN IRELAND}

Cessation clauses formed part of section 21, 'Revocation of declaration', of the Refugee Act 1996 and section 14, 'Revocation of or refusal to renew subsidiary protection', of S.I. No. 518/2006 - European Communities (Eligibility for Protection) Regulations 2006. Sections 21(1) (a) to (g) were commonly known as cessation and exclusion clauses, giving effect in Irish law to Articles $1 \mathrm{C}$ and $1 \mathrm{~F}$ of the 1951 Convention relating to the Status of Refugees, as clarified in Adegbuyi $v$. Minister for Justice and Law Reform [2012] IEHC 484, para. 37.

The International Protection Act 2015 repealed the 1996 Act and revoked the 2006 Regulations. Cessation is now provided for in section 9 of the 2015 Act in respect of persons with refugee status and section 11 of the 2015 Act in respect of persons with subsidiary protection status.

Cessation of Refugee Status under section 9 and subsidiary protection under section 11 form grounds for revocation under section 52 of the 2015 Act. $^{15}$

\subsection{PROPOSAL TO REVOKE}

If the Minister for Justice and Equality (Minister) via the Ministerial Decisions Unit (MDU) of INIS were to issue a proposal to revoke refugee/subsidiary protection status under section 52(4), the individual affected would be entitled to make representations to the Minister within 15 working days. ${ }^{16} \mathrm{~A}$ case-by-case

Section 52 of the 2015 Act states that: ' (1) The Minister shall, in accordance with this section, revoke a refugee declaration given to a person if satisfied that - (a) the person should have been or is excluded from being a refugee under section 10, (b) the person has, in accordance with section 9, ceased to be a refugee, or (c) misrepresentation or omission of facts, whether or not including the use of false documents, by the person was decisive in the decision to give the person a refugee declaration. (2) The Minister may, in accordance with this section, revoke a refugee declaration given to a person if satisfied that - (a) there are reasonable grounds for regarding him or her as a danger to the security of the State, or (b) the person, having been by a final judgement convicted, whether in the State or not, of a particularly serious crime, constitutes a danger to the community of the State. (3) The Minister shall, in accordance with this section, revoke a subsidiary protection declaration given to a person if satisfied that - (a) the person should have been or is excluded from being eligible for subsidiary protection under section 12, (b) the person has, in accordance with section 11, ceased to be eligible for subsidiary protection, or (c) misrepresentation or omission of facts, whether or not including the use of false documents, by the person was decisive in the decision to give the person a subsidiary protection declaration'. 
assessment of all circumstances, including non-refoulement and European Convention on Human Rights (ECHR) Article 8 rights, is undertaken. ${ }^{17}$

UNHCR Ireland noted that under section 21(4)(a) of the 1996 Act, ${ }^{18}$ INIS was obliged to share a copy of any proposal to revoke status with their office. In some cases as deemed necessary, UNHCR Ireland has made submissions to INIS in response to such proposals, setting out any concerns around the reasons for the proposal to revoke and pointing to relevant guidance. ${ }^{19}$

Section 52(5) of the 2015 Act also provides for a copy of the proposal to revoke to be sent to UNHCR Ireland when issued to a refugee or subsidiary protection beneficiary.

In accordance with sections 9(3) and 11(3) of the 2015 Act, beneficiaries are given the opportunity to invoke compelling reasons of past persecution or serious harm in order to avoid cessation of refugee status or subsidiary protection in some circumstances (e.g. where the circumstances upon which the beneficiary was recognised as a refugee cease to exist but there are compelling reasons for their refusal to avail of their country of origin's protection). This is consistent with EU law on the same (see Section 2.1). The IRC welcomed sections 9(3) and 11(3). ${ }^{20}$

\subsection{DECISION TO REVOKE}

Where the Minister decides thereafter to revoke the status, the individual may appeal such a refusal to the Circuit Court within ten working days in accordance with section 52 of the 2015 Act. ${ }^{21}$ A revocation appeal to the Circuit Court is not a judicial review. The statutory remedy is an appeal, which may then either affirm the revocation or direct the Minister to withdraw it. This point was elaborated in Nz.N v. Minister for Justice and Equality [2014] IEHC 31. The case concerned revocation on the basis of the appellants using false identities. Of interest to the present study (albeit in the context of the 1996 Act), the High Court clarified the statutory appeal procedure:

The powers of the Court on an appeal against a revocation of refugee status is to determine whether the decision to revoke the declaration was correctly made and should be confirmed, or whether the decision was

17 Interview with INIS, October 2018.

18 Refugee Act 1996, section 21(4)(a): notice under subsection (3)(a) shall include a statement that the person concerned may make representations in writing to the Minister within 21 days of the issue by the Minister of the notice. 
wrong and should be withdrawn. The Court can consider all the evidence which was before the Minister and hear oral evidence from the appellant and any witnesses called by either party in determining the appeal. The Court can come to its own view as to whether the decision to revoke is appropriate or should be withdrawn (para. 31).

There is no legislative provision for an oral hearing as part of this procedure. However, appellants have been given the opportunity to give oral evidence under the 1996 Act as was the case in Hussein v. Minister for Justice and Law Reform [2014] IEHC 130.

UNHCR Ireland is generally notified of final decisions to revoke status. ${ }^{22}$

As outlined above, revocation appeals moved from the High Court under the Refugee Act 1996 to the lower level Circuit Court upon commencement of the 2015 Act. Judges in the Circuit Court deal with a variety of areas of law and their level of experience with protection revocations is unknown. In addition, the Circuit Court generally gives ex tempore decisions without issuing written judgments. $^{23}$

\subsection{GROUNDS FOR REVOCATION/CESSATION INCLUDING RETURN TO/CONTACT WITH COUNTRY OF ORIGIN}

INIS noted that international protection statuses are not reviewed once a declaration is made unless special circumstances arise. ${ }^{24}$ In this case, a 'review' may result in revocation, including on cessation grounds. (As noted above there have not yet been revocations under the 2015 Act.) While grounds for revoking an individual's refugee status can vary from case to case, the main ground that arises is where it has been found that the applicant provided false or misleading information to the Office of the Refugee Applications Commissioner (now International Protection Office) or the Refugee Appeals Tribunal (now International Protection Appeals Tribunal) during the course of their asylum application. ${ }^{25}$ This arose in Gashi v. The Minister for Justice, Equality and Law

\footnotetext{
Interview with UNHCR Ireland, September 2018. UNHCR Ireland clarified that they would not ordinarily have contact with the person of concern unless they contact UNHCR directly.

Input from EMN Legal Consultant, Patricia Brazil, September 2018.

Interview with INIS, October 2018.

Parliamentary Question, 16 January 2013 [1743/13]. Deputy Caoimhghín Ó Caoláin asked the Minister for Justice and Equality the number of times he has revoked the refugee status of recognised refugees awarded by his Department during his period as Minister; the reasons for same; and if he will make a statement on the matter. Parliamentary Question, 26 February 2014 [9747/14]. Deputy Mick Wallace asked the Minister for Justice and Equality if he will set out in tabular form the annual figures for ministerial decisions made to revoke refugee status since 2005, alongside
} 
Reform [2010] IEHC 436. The case concerned revocation on the basis of the appellants using false identities. Of interest to the present study, the judge noted that: 'The question to ask is whether the application for protection would have been determined differently had the information not been misrepresented or concealed' (para. 25).

The Law Society recommended that only the consideration of 'misrepresentation or omission of facts, whether or not including the use of false documents' should be limited to circumstances where there was fraudulent or intentional misrepresentation regarding material facts which were core to the application and declaration. ${ }^{26}$

UNHCR Ireland also observed that grounds that arise in revocation proposals and/or decisions have included return to the country of origin, criminality, fraud and misrepresentation. ${ }^{27}$ UNHCR Ireland further commented that travel to the country of origin for family reasons (e.g. to visit a sick relative) has arisen in the context of cessation and revocation proposals. ${ }^{28}$

\subsubsection{Travelling to or contacting authorities in the country of origin}

Under section 3 of the now repealed Refugee Act 1996, refugees were entitled to 'the same rights of travel in or to or from the State as those to which Irish citizens are entitled'. This was carried over to the 2015 Act, section 53. Section 55 of the International Protection Act 2015 governs the issuance of travel documents. Under the circumstances that a travel document has been obtained, the International Protection Act 2015 states:

A qualified person shall be entitled ... subject to section 55, to the same rights of travel in or to or from the State as those to which Irish citizens are entitled. ${ }^{29}$

The Citizens Information Board states that beneficiaries of international protection may travel freely in and out of the State with the travel document. Holders may travel to most EU states. A re-entry visa is not required for persons travelling on a travel document. ${ }^{30}$

the annual figures for successful appeals of those decisions since 2005; if he will set out categories showing his reasons for those decisions since 2005; and if he will make a statement on the matter.

Law Society (2015). Submission on the General Scheme of the International Protection Bill. Dublin: Law Society. Interview with UNHCR Ireland, September 2018.

Ibid.

International Protection Act 2015, Section 53.

Citizens Information, 'Travel documents for people with refugee or subsidiary protection status', www.citizensinformation.ie/en/moving_country/asylum_seekers_and_refugees/refugee_status_and_leave_to_rema in/travel_documents_for_refugees.html. 
When applying for a travel document refugees do not have to show they were unable to obtain a national passport in legislation nor in practice. However, the application suggests that refugees must provide evidence that they were unable to obtain a passport. ${ }^{31}$

According to the Asylum Information Database, the primary limitation on use of travel documents is that the holder may not use the document to travel to the country of origin/persecution. This information was provided to the Irish Refugee Council by INIS in March 2018. ${ }^{32}$

The travel document explicitly states that refugees cannot travel to their country of origin as highlighted in Adegbuyi v. Minister for Justice and Law Reform [2012] IEHC 484, para. 15:

...The following day he applied for the travel document and personally collected the travel document issued to him on or about 17th July 2007 at the offices of the GNIB at Burgh Quay. That document clearly states on its face that it was valid for travel to all countries except Nigeria.

Mr. Adegbuyi, a Nigerian national, was a recognised refugee in Ireland.

A travel document is only issued to beneficiaries of subsidiary protection where they are unable to obtain a national passport. Section 55(2)(b) of the International Protection Act 2015 states that the 'Minister need not issue a travel document' where 'the person is a person in respect of whom a subsidiary protection declaration is in force and who is able to obtain a national passport'. UNHCR Ireland noted that beneficiaries of subsidiary protection are asked to include evidence with their application for a travel document showing that they were unable to get a passport. ${ }^{33,34}$ There are no geographical limitations attached to the travel document as there are no travel restrictions imposed upon beneficiaries of subsidiary protection. ${ }^{35}$

31 Department of Justice and Equality, 'Travel document application form', www.inis.gov.ie/en/INIS/Travel\%20Document\%20Form\%20-

\%20January2017.pdf/Files/Travel\%20Document\%20Form\%20-\%20January2017.pdf.

32 AIDA, 'Travel Documents', www.asylumineurope.org/reports/country/republic-ireland/contentprotection/movement-and-mobility/travel-documents\#footnote8_622iy7o.

Interview with UNHCR Ireland, September 2018.

34 Section 1B of the travel document application: www.inis.gov.ie/en/INIS/Travel\%20Document\%20Form\%20\%20January2017.pdf/Files/Travel\%20Document\%20Form\%20-\%20January2017.pdf.

$35 \quad$ Interview with INIS, October 2018. 


\subsubsection{Cessation and revocation on grounds of travelling to or contacting authorities in the country of origin}

The cessation provisions in the 2015 Act relevant to the scope of this study, namely travelling to, or contacting authorities in, the country of origin, are section 9(1) paragraphs (a) and (d):

A person shall cease to be a refugee if he or she-

(a) has voluntarily re-availed himself or herself of the protection of the country of nationality;

(d) has voluntarily re-established himself or herself in the country which he or she left or outside which he or she remained owing to fear of persecution.

These provisions do not apply in the context of cessation of subsidiary protection status (section 11).

General guidance is available from the UN Refugee Agency (UNHCR) globally on cessation, including on the grounds of voluntary re-establishment, but no guidance exists in Ireland specifically. In relation to determining whether a person has 're-availed' of their country of origin's protection, UNHCR noted that there is a difference between travelling to the country of origin for a short time and reavailing of that country's protection or re-establishing oneself there. ${ }^{36}$ According to UNHCR guidance, re-availing of national protection implies three requirements; voluntariness on the part of the refugee, intention to re-avail him/herself of the protection of the country of nationality, and the actual availment of such protection.

The voluntary nature of the act is required: 'If the refugee does not act voluntarily, he will not cease to be a refugee', for example if instructed by the country of residence to apply to his consulate for a national passport. ${ }^{37}$

A visit to a country of origin by a refugee (not with a national passport but, for example, with a travel document issued by their country of residence), should be judged on its individual merits:

Visiting an old or sick parent will have a different bearing on the refugee's relation to his former home country than regular visits to that country spent on holidays or for the purpose of establishing business relations. ${ }^{38}$ 
This applies in relation to a refugee voluntarily re-availing themselves of the protection of the country of origin and/or voluntarily re-establishing themselves there.

A refugee's 'voluntary re-establishment' in the country of persecution, according to UNHCR guidance, should be understood as meaning that the refugee has returned with a view to permanently residing there; a

temporary visit by a refugee to his former home country, not with a national passport but, for example, with a travel document issued by his country of residence, does not constitute 're-establishment' and will not involve loss of refugee status [under that clause]. ${ }^{39}$

UNHCR Ireland observed that in their experience contact with countries of origin could result in revocation, in accordance with the cessation provisions in the 2015 Act, being explored by Irish State authorities. In one cited instance, which fell under the 1996 Act, UNHCR Ireland received a copy of a proposal to revoke the protection status of a person who appeared to have registered as a candidate for elections in the country of origin. The proposal to revoke status indicated section 21(1)(a) of the Refugee Act 1996, re-availing of the protection of the country of origin, as the ground for the proposed revocation. ${ }^{40}$

UNHCR Ireland cited their knowledge of a case involving a refugee who returned home for a number of weeks with a passport he obtained while a refugee. When he returned to Ireland, his travel documents were taken and his status was subsequently revoked, including on the basis that he wished to return home and re-establish himself there. UNHCR Ireland noted further cases where the persons concerned wanted to return home, so they alerted the Irish authorities to this and their status was revoked on that basis. ${ }^{41}$ In 2014, the Minister reported in response to a Parliamentary Question that if a person with refugee status informs the Department of Justice and Equality that they wish to return to their country of origin, it is necessary to revoke their status to allow them to return. ${ }^{42}$

UNHCR Ireland noted that beneficiaries contact their office infrequently to get advice on whether they can travel to neighbouring countries or their country of origin to visit sick relatives. Representatives noted that they advise beneficiaries

UNHCR Handbook, Para. 134.

Interview with UNHCR Ireland, September 2018.

Ibid.

Parliamentary Question, 26 February 2014 [9747/14]. See oireachtasdebates.oireachtas.ie. 
against travelling to countries of origin. ${ }^{43}$ UNHCR Ireland has also been alerted to some cases in recent years where Irish State authorities apparently directed beneficiaries to contact authorities in their country of origin in order to obtain death certificates or birth certificates for social welfare purposes, for example. ${ }^{44}$

INIS noted that in certain circumstances travel to the country of origin/persecution may suggest that protection from the country of origin is no longer needed or that the information provided during the asylum process was false. ${ }^{45}$ In Adegbuyi v. Minister for Justice and Law Reform [2012] IEHC 484, Mr Adegbuyi was found to have travelled to Nigeria on a number of occasions after being granted refugee status in Ireland. The Minister noted that travelling on his Nigerian passport to Nigeria 'may indicate that you no longer require the protection of this country' (para. 18). The proposal to revoke stated: '...it is quite clear that you have voluntarily re-availed yourself of the protection of your country of nationality' (para. 25). The court held that the Minister was correct to revoke the appellant's refugee status (para. 56).

It was further reasoned:

While the Court would have misgivings relating to the bona fides of the application for asylum in view of the very obvious misrepresentations on the issue of the Heathrow passport, the Court would have approached the appeal from the premise that the applicant was a refugee but that the evidence that he had returned to Nigeria and engaged in a court process wherein the Nigerian police had investigated his complaints of forgery was adequate to support the conclusion that he had voluntarily re-established himself in Nigeria (para. 35).

And later in the judgment referring to the Minister's initial decision:

The Minister revoked Mr. Adegbuyi's refugee status on the basis that he was a declared refugee but because of his early return to Nigeria, his engaging with the Nigerian State authorities in pursuing civil and criminal processes, his continuing with his position as a lecturer at the University of Lagos and his residence at his previous address he found that the appellant had voluntarily re-availed of State protection and re-established himself in Nigeria (para. 45).

$43 \quad$ Interview with UNHCR Ireland, September 2018.

44 Ibid. UNHCR Ireland provided an example of a woman with refugee status who was the guardian of child family members after their parents had died. They were directed to contact the national authorities in their country of origin to obtain death certificates. 
In Hussein v. Minister for Justice and Law Reform [2014] IEHC 130, Mr Hussein appealed the Minister's proposal to revoke his refugee status. It came to the attention of the Minister based on information provided by the UK that the appellant had travelled to his country of origin - Sudan. Prior to the formal proposal to revoke the decision, the Minister's official requested fingerprints. They were then able to confirm that the appellant had travelled to Sudan postrefugee declaration in Ireland and that he was in possession of a valid Sudanese passport.

The formal proposal to revoke the appellant's refugee status cited a number of reasons, including: (1) failure to submit the valid Sudanese passport which indicated that he wished to retain the protection of Sudan; (2) return to Sudan post-declaration, indicating that the appellant had 'no fear in relation to [his] country of origin' and (3) false and misleading information provided during the asylum process.

The appellant was given the opportunity to give oral evidence. The court held that the burden of proof rests on the appellant (para. 41). The High Court upheld the Minister's decision to revoke the appellant's refugee status and rejected the appeal (para. 49).

Justice Mac Eochaidh in obiter commented that it is not necessary to decide whether the Minister was correct in deciding that the appellant, by returning on a number of occasions to Sudan on his own passport had thereby availed of the protection of his country of origin such that refugee status was no longer warranted (para. 50).

While not set out in legislation, INIS noted that in certain circumstances contact with official authorities may suggest that protection from the country of origin is no longer needed or that the information provided during the asylum process was false. ${ }^{46}$ 



\section{SECTION 4}

\section{Consequences of a decision to revoke}

\subsection{CONSEQUENCES OF A DECISION TO REVOKE}

The International Protection Act 2015 does not expressly provide for a specific deportation process where revocation of status has taken place. ${ }^{47}$ INIS noted that section 3 of the Immigration Act 1999 applies. A decision to revoke refugee protection under the International Protection Act 2015 is followed by a notice of the Minister's intention to issue a deportation order ${ }^{48}$ under section 3 . The person will have 15 days to: consent to deportation; leave the State voluntarily within a specified period; or make submissions to the Minister as to why a deportation order should not be made against him or her. The Minister must consider any such representations before deciding the matter. In determining whether to make a deportation order, the Minister must also have regard to the criteria listed under section 3(6) of the 1999 Act, including humanitarian considerations. Leave to remain may be explored in this context. ${ }^{49}$

UNHCR Ireland noted that it is not always possible to return a person to their country of origin after a revocation decision. In that case leave to remain may be explored in line with the provisions discussed above. ${ }^{50}$

\subsection{EFFECT ON DEPENDANTS/FAMILY MEMBERS}

The residence status of family members who do not have a protection status in their own right and who have a derived status based on the status of the refugee or beneficiary of subsidiary protection may be affected by a decision to revoke a declaration of international protection. After a decision to revoke a sponsor's international protection declaration, the dependant/family member may apply for leave to remain, a change of status under the Immigration Act 2004, or apply for asylum in their own right. ${ }^{51}$ INIS noted that case-by-case decision applies to persons with a family reunification permission that is dependent on the sponsor's status. Nasc observed that the Bill (and subsequently the Act) did not address the issue of what would happen to the family of those refugees whose status was revoked. ${ }^{52}$

\footnotetext{
Comments received from INIS, 21 February 2019. Interview with INIS, October 2018.

Ibid.

Interview with UNHCR Ireland, September 2018.

Interview with INIS, October 2018.

Nasc (2015). Recommendations on the International Protection Bill 2015. Cork: Nasc.
} 
NA (Somalia) and UM (Afghanistan) v. Minister for Justice \& ors; UM (Afghanistan) (a minor) v. Minister for Foreign Affairs and Trade \& anor [2017] IEHC 741 dealt with the impact of the decision to revoke a sponsor's refugee declaration on the citizenship status of children who had been granted Irish passports on the basis that their parents were lawfully resident in the State at the date of their birth. This case dealt with citizenship rather than immigration permission. The State position was that on foot of the revocation of the father's refugee status, which was determined to be void ab initio, rendered subsequent grants of citizenship void ab initio. This was upheld by the High Court.

The judgment noted that the father, UM, had his refugee status revoked both for false/misleading information, and also because he was found to have returned to Afghanistan voluntarily subsequent to the grant of refugee status. 


\section{SECTION 5}

\section{Conclusion}

Pursuant to paragraphs (1) and (4) of Article 1C, the 1951 Convention relating to the Status of Refugees may cease to apply where the refugee has voluntarily reavailed himself of the protection of the country of origin, or where he has reestablished himself there, respectively.

Cessation under Articles 11 and 16 form grounds for revocation under Articles 14 and 19 of the Qualification Directive recast. Articles 44, 45 and 46 of the recast Asylum Procedures Directive provide for procedural safeguards where international protection statuses may be ended, revoked or not renewed.

Irish law mirrors international and EU law and provides for cessation consistent with the Refugee Convention (see Section 2). Sections 9 and 11 of the International Protection Act 2015 govern cessation of refugee and subsidiary protection in Ireland. Cessation of Refugee Status under section 9 and subsidiary protection under section 11 form grounds for revocation under section 52 of the 2015 Act.

Nevertheless, while cessation is permitted under Irish law, it is not often applied in practice. No decisions had been issued to revoke a refugee/subsidiary protection declaration by the Minister under section 52 of the 2015 Act at the time of research (as at 21 February 2019).

National-level information on the reasons for cessation/revocation is not collected. In addition INIS noted that Ireland does not have a system of exit controls at the border. Therefore information on persons travelling to their country of origin is not captured in any data sources.

\section{Cessation and the revocation procedure}

If the Minister via the MDU of INIS were to issue a proposal to revoke refugee/subsidiary protection status under section 52(4), the individual affected is entitled to make representations to the Minister within 15 working days. In accordance with sections 9(3) and 11(3) of the 2015 Act, beneficiaries are given the opportunity to invoke compelling reasons of past persecution or serious harm in order to avoid cessation of refugee status or subsidiary protection in some 
circumstances. Where the Minister decides thereafter to revoke the status, the individual may appeal such a refusal to the Circuit Court within ten working days in accordance with section 52 of the 2015 Act.

The 2015 Act brought about some changes in this area of law. Most importantly, revocation appeals moved from the High Court to the lower level Circuit Court upon commencement of the 2015 Act. Judges in the Circuit Court deal with a variety of areas of law and their level of experience with protection revocations is unknown.

\section{Main trend in Ireland as regards revocation}

While grounds for revoking an individual's refugee status can vary from case to case, the main ground that arises is where it has been found that the applicant provided false or misleading information during the course of their asylum application; as was the case in Gashi.

\section{Travelling to the country of origin and cessation/revocation}

Refugees may not travel to their country of origin. This restriction does not apply to beneficiaries of subsidiary protection. INIS noted that in certain circumstances travel to the country of origin/persecution may suggest that protection from the country of origin is no longer needed or that the information provided during the asylum process was false; as was the case in Adegbuyi.

\section{Consequences of a decision to revoke}

As INIS noted, a decision to revoke refugee protection may be followed by a notice of the Minister's intention to issue a deportation order. Leave to remain may be explored at this stage.

The residence status of family members who do not have a protection status in their own right and who have a derived status based on the status of the refugee or beneficiary of subsidiary protection may be affected by a decision to revoke a declaration of international protection. After a decision to revoke a sponsor's international protection declaration, the dependant/family member may apply for leave to remain, a change of status or apply for asylum in their own right. 

EMN Ireland,

Economic and Social

Research Institute,

Whitaker Square,

Sir John Rogerson's Quay,

Dublin 2, Ireland

Telephone +353 $1 \mathbf{8 6 3 2 0 0 0}$

Email emn.ireland@esri.ie

Web www.emn.ie / www.esri.ie

Twitter @EMNIreland

ISBN 978-0-7070-0484-6 